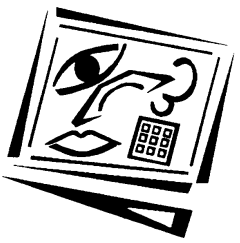

\title{
Developing a better understanding of technology based pedagogy
}

\author{
Ping Gao, Doris Choy, Angela F. L. Wong, and Jing Wu \\ Nanyang Technological University
}

\begin{abstract}
The focus of this paper is to present the major qualitative findings from a one year, mixed methods study that explores a cohort of preservice teachers' process of learning to teach with information and communication technology (ICT) across their teacher preparation program in Singapore. This study suggests a variation in the preservice teachers' technology competency, stances, decision making and actions in using ICT for classroom teaching and learning. The majority of the participants seemed to be unable to translate into teaching practice their increased technological competency and espoused constructivist orientation gained from the coursework. They tended to use ICT to improve and enhance teacher centred instruction on a regular basis during the teaching practicum. However, three focus participants were also able to use ICT to engage their students in student centred learning. They began to demonstrate their leadership potential in influencing others to use ICT for enhancing student learning. The findings suggest that preservice teachers may need more guidance, modelling and collaboration to develop a better understanding of technology based pedagogy from their own practice so that they can synthesise their constructivist orientation, student centred teaching approaches, and effective use of ICT.
\end{abstract}

\section{Introduction}

For the last two decades, special attention has been given to preparing a new generation of teachers who are able to apply a wide spectrum of advanced information and communication technologies (ICT) to meet the diverse learning needs of their students worldwide (British Columbia Ministry of Education, 1999; International Society for Technology in Education, 2000; Singapore Ministry of Education, 2002; National Council for Accreditation of Teacher Education, 1998). Accordingly, there has been an accumulation of a sizable body of studies on the new discipline of teacher learning with information technology (Willis \& Mehlinger, 1996; Willis, Thompson \& Sadera, 1999). However, a majority of the existing studies provide snapshots instead of a more complete picture of how preservice teachers were being prepared for technology integration in classroom teaching and learning. For example, after analysing 68 studies on the strategies used to prepare preservice teachers for using technology during teacher preparation, Kay (2006) noted that "most research examined attitudes, ability or use, but rarely all three" (p. 383). Furthermore, a repeated finding suggested that most preservice and beginning teachers are unable to use innovative and creative ways for promoting students' higher order thinking (Andersson, 2006; Dawson, 2006; Kay \& Knaack, 2005; Wright \& Wilson, 2005). Swain (2006) suggested that one way to start this investigation is to carefully examine preservice teachers' perceptions of their success in using ICT in their daily lives and in teaching and whether there was a change in their views and daily practice. 


\section{Purpose of this study}

The purpose of this study was to fill the gap by examining changes in preservice teachers' skills, perceptions and actions in using ICT for classroom teaching and learning throughout their initial teacher preparation program in the Singapore context. Specifically, we focused on whether the preservice teachers used ICT, and why and how they used it. We intended to answer the following four research questions:

1. What are the changes of the participants' technology skills during their teacher preparation program?

2. What stances do the focus participants develop in the use of ICT for classroom teaching and learning?

3. Why do they choose to use or not use ICT during their teaching practicum?

4. How do they use ICT in their own classroom during the teaching practicum?

\section{Related literature}

The theoretical framework of this study is based on the constructivist theory of teacher learning, which articulates that learning to teach is to bring the sorts of changes in knowledge, skills, and beliefs that may occur through teacher education (Ball \& McDiarmid, 1987; Brophy, 1991; Hollingsworth, 1989). Constructivism maintains that individuals create or construct their own new understanding or knowledge through the interaction of what they already know and believe and the ideas, events, and activities with which they come in contact (Cannella \& Reiff, 1994; Lerman, 1989).

Information technology can be used in a variety of ways and for different purposes in the classroom. There have been many attempts to describe how information technology should be used in educational settings. McNabb, Hawkes and Rouk (1999) analysed and organised teachers' use of information technology into the following four categories: 1) Basic uses of technology; 2) Instructional use of technology; 3) Administrative use of technology; and 4) Professional development uses of technology. The notion of constructivist learning leads a shift in the use of information technology in the classroom: from using ICT as "instruction tools" to enhance conventional teaching, to using ICT as "cognitive tools" to promote meaningful student learning that is active, constructive, intentional, authentic and cooperative (Jonassen, Peck \& Wilson, 1999; Reeves, 1998).

A review of research studies on preparing preservice teachers' for the use of ICT suggested that most studies focused on the impact of technology course(s) on preservice teachers' technology competency and their attitudes toward technology integration. For example, researchers found that preservice teachers experienced an improvement in technology proficiency and comfort level (Bird \& Rosaen, 2005; Judge \& O'Bannon, 2007; Lipscomb \& Doppen, 2005; Vannatta \& Beyerbach, 2000) and a positive change in attitude towards technology use (Brown \& Warschauer, 2006; Johnson \& Howell, 2005; Wright \& Wilson, 2005). However, teacher educators (Bullock, 2004; Dexter \& Riedel, 2003; McIntyre \& Tlusty, 1995) articulated the importance of socially situated learning in the school based context. Mullen (2001) noticed that preservice teachers' technology field practices have a positive impact on their attitudes toward teaching with technology in the future. Stulmann (1998) found that as a result of applying technology in their teaching as student teachers, the beginning teachers became more comfortable with technology integration after becoming full-fledged teachers. 
However, other researchers have cautioned that preservice teachers do not appear to be ready to use ICT in their teaching (Kay, 2006; Moursund \& Bielefeldt, 1999; Russell, Bebell, O'Dwyer \& O'Conner, 2003; Swain, 2006). The reasons cited included insufficient exposure to technology integration in teacher preparation programs (Brown \& Warschauer, 2006; Strudler, McKinney, Jones \& Quinn, 1999), and inadequate preparation for teaching with technology (CEO Forum on Educational Technology, 2000; Moursund \& Bielefeldt, 1999). Specifically, there was limited use of technology that promoted higher order thinking and cooperative learning during the field placements (Bird \& Rosaen, 2005; Brown \& Warschauer, 2006; Kay \& Knaack, 2005; Wright \& Wilson, 2005).

\section{Design of the study}

We employed the mixed methods design to approach this complex inquiry of learning to teach with information technology from several directions. We used the survey method to identify any change in technology competency, their intention for using ICT and their preferred action before the practicum and real actions for using ICT during the practicum, at three points of data collection. Concurrently, we used qualitative research methods to gain insights into how the ten purposefully selected focus participants constructed their understanding of technology based pedagogy.

\section{Context of the study and participants}

The participants in this study were a cohort of 310 preservice teachers enrolled in the Postgraduate Diploma in Education (Primary) initial teacher preparation (ITP) program at the National Institute of Education (NIE), Singapore. Before enrolling in the program, all had completed bachelor degrees from local or internationally accredited universities. In addition, most of them had had contract teaching experience ranging from a month to a year at the assigned local schools. During their contract teaching, they worked as full time teachers with some guidance from experienced teachers at the schools. During the one-year initial teacher preparation (ITP) program at NIE, they took courses in educational studies (educational foundation courses) and curriculum studies (methods courses). They were enrolled in a mandatory core educational studies course entitled "ICT for Engaged Learning". During the course, they learned pedagogy in integrating technology into classrooms teaching and learning with an emphasis on student centred learning. For the final project, they worked in pairs to design a student centred learning package that could be used in their future teaching. The last component of the ITP program consisted of a ten-week teaching practicum, where they taught in schools under the close supervision of their cooperating teachers and a university supervisor. After completing the program, they were appointed as full-fledged teachers.

\section{Survey data collections and analysis}

As the focus of this paper is to present the qualitative findings of this study, we will provide only a brief description of the survey data collection and analysis (see Choy, Wong \& Gao, 2008, for detailed information about survey instrument development, validation and data analysis). We administered the survey at the three points in the participants' teacher preparation program: the first session of the ICT course (August, 2006), the last session of the ICT course (Oct, 2006) and after the teaching practicum (May, 2007). We chose to analyse and present the results of the three open-ended 
questions from the 118 preservice teachers who completed all three sets of surveys. Although these answers are qualitative in nature, we first read, coded, recoded the data and categorised them into the themes, and then quantified the data according to the frequency of the responses. For the purpose of clarity, we refer to these 118 preservice teachers as the "general participants" to differentiate them from the ten "focus participants" who were purposefully selected to participate in the qualitative component of the study.

\section{Qualitative data collection and analysis}

The selection of the ten focus participants for the qualitative components of the study was based on self reported levels of ICT skills, indicated in responses to the pre-ICT course survey. Among the ten focus participants, three identified themselves as possessing a high level of technology skills in using ICT for student centred learning, four a medium level and three a low level. We used purposeful sampling to select the focus group participants. This is to ensure that the range of technology skills is representative of that in the general participants, and to avoid an accidental clustering of participants within the range. We interviewed each focus participant twice, once during the ICT course (September, 2006) and the other at the end of the teaching practicum (May, 2007). Each interview lasted around 30-50 minutes, and was verbatim transcribed. Additionally, we had two focus group discussions, one at the beginning (February, 2007) and the other in the middle of the teaching practicum (May, 2007). We conducted and video recorded 13 observations (one observation usually consisting of two 30-minute lessons) of the seven participants who felt comfortable to be observed and with the permission from the school administrators. We wrote field notes for each observation. Immediately after each observation, we held a brief post-observation discussion with the focus participant to probe his or her reflections. We also collected hard copies of these focus participants' lesson plans and samples of their students' work during their observed lesson(s).

We adopted an across phase mixed methods analysis (Onwuegbuzie \& Teddlie, 2003), and the on-going multi-phased data analysis (Miles \& Huberman, 1984) for data analysis. We started to analyse the qualitative analysis after collecting the first set of data, and continued throughout the duration of the study. We adopted the constant comparative method of data analysis (Glaser \& Strauss, 1967) to make sense of the meaning by triangulating investigators, methods and data (Lincoln \& Guba, 1985). For example, after the first round of interviews, two members in the research team started a preliminary explorative content analysis to independently analyse each focus participant, who was treated as a unit of analysis. We followed the coding steps outlined by Strauss (1987): open coding, axial coding, and identifying emerging themes while writing memos. We then compared the coding, and arranged the emerging themes into the three major categories: perceptions, actions, and contexts for decision making. Furthermore, we identified and verified the categories between the two interviews for each focus participant and among the focus participants. We verified the interview data with observation notes, videoed lessons and reflection data. In order to establish confidence in the trustworthiness of the findings (Patton, 1990), we conducted on-going peer review of the data analysis among the research team members. At the final phase of the data analysis, we created a profile of each participant and conducted "member check" (Lincoln \& Guba, 1985) for the interview transcripts and the profile for each focus participant. 


\section{Major findings}

We will start this section with a brief presentation of the survey findings related to the changes of 118 general participants' technology skills across the three points of quantitative data collection. Then we will present the changes in views on using ICT for the classroom teaching and learning of the ten focus participants generated from the interviews. We will also use the answers to three open ended questions in the survey to provide a broad picture of the views of the general participants in this respect. Since the ten focus participants varied in stances and actions in their use of ICT for classroom teaching and learning, we will identify and present two consistent patterns, namely using ICT as a presentation tool to enhance their own instruction, and using ICT to promote student learning.

\section{Changes in technology skills}

One of the quantitative results suggests that the general participants self reported a consistent gain for the technology skills across their teacher preparation program (Figure 1). There are two interpretations for this finding. One interpretation may suggest that the general participants really gained more technology skills during the practicum. However, the focus participants did not indicate any technology gains during the post-practicum interview. The other interpretation may suggest that the general participants began to perceive that they had possessed sufficient skills when comparing themselves with their cooperating teachers during their practicum.

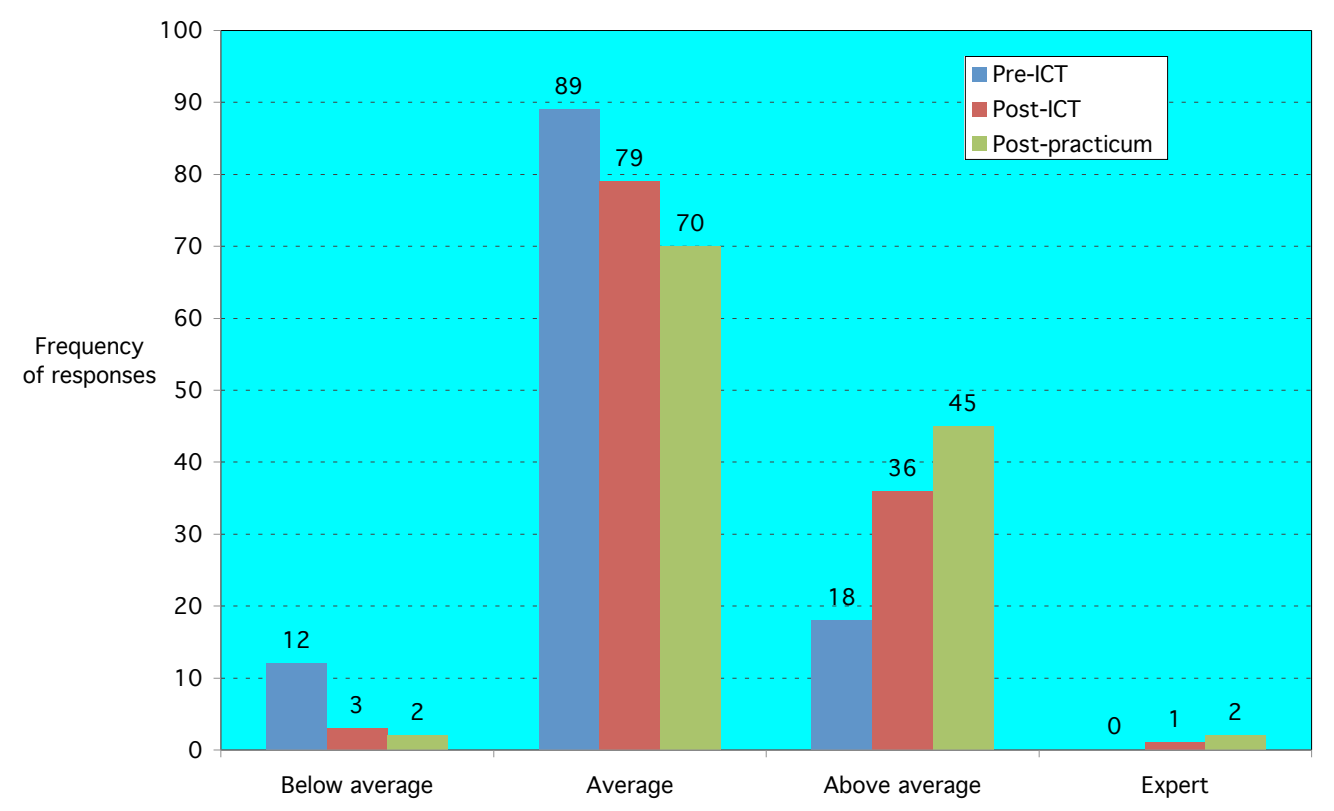

Figure 1: Changes in general participants' self perceived technology skills

\section{Changes in views}

One recurring theme from the interviews indicated that all the focus participants held an optimistic and constructivist orientation towards teaching and learning during the 
first interview that took place after the fourth session of the ICT course. For example, when talking about their pedagogical beliefs, all the focus participants emphasised the importance of having students at the centre of learning. One focus participant commented: "They [students] discover, and then they say 'Hah, that's how it relates.' If you tell them, they may not remember. I think that is most important for me." Another focus participant, who rated herself at a high comfort level for using ICT for student centred learning, articulated her general beliefs in teaching:

Basically I believe teaching is more than imparting knowledge. It's also to impart an attitude and philosophy about life also, yeah ... I think, increasingly we are moving away from teacher-centric teaching to more learner-centric ... It's more a constructivist approach whereby students are expected to find out certain things for themselves because when they find out certain things for themselves, they learn better, rather than being force-fed the information.

The other participants echoed:

Good teaching is to let students know how to learn ... how to find out the way to solve problems, how to collect the information they want and they can, how can they make them more confident about themselves.

However, the majority of the focus participants could not relate their general pedagogical beliefs to using ICT for promoting student centred learning in their future classroom teaching. For example, during the first interview, their ideas about effective use of ICT focused primarily on using ICT as instruction tools to enhance their teaching. They saw the value of ICT as "a resource for references" or "alternative tools to produce work". Its role was to "replace a teacher in time of urgency", "lighten the workload of a teacher" and "save time by speeding up the pace of teaching". As a result, they had difficulty in articulating their thinking about how to connect constructivist orientations with the use of ICT for student centred learning. For example, one focus participant commented: "Integration is still a difficult thing. I can see that the integration of technology into business is available ... yet, it's a challenge, trying to integrate [ICT into] teaching." Another participant talked about his doubt: "I am still pondering on it."

Consequently, they seemed to hold some misconceptions about a connection between using ICT and applying student centred approaches. For example, in the first interview, one focus participant commented that "whenever I hear the phrase 'student centred use of ICT', I will automatically associate it with the situation where each student works independently in front of a computer". Another misconception about technology integration is "to integrate software to students' learning activities". One focus participant shared his plan to "allocate more time whereby the teacher is not the one delivering the lesson ... We [will] rely more on CDs, interactive CDs that we think are good."

In the second interview after the practicum, when the focus participants talked about their beliefs in teaching and learning and technology integration, they seemed to be more conservative and realistic about the implementation of student centred learning. For example, one participant, who had strong constructivist beliefs, articulated her professional reasoning for keeping a balance between student centred and teacher centred approaches: 
I think teaching has moved away from the teacher-based or [teacher-]centred methods to more student involvement. However, I still think that sometimes we still have to be more instruction in our teaching because some methods or some teaching will still be more effectively or efficiently taught if the teacher do like teacher demo or teacher hands on.

The participant further argued that a teacher should be an "information provider and give presentations ... except when students have hands on experience" (Second Interview). Reflecting on her own stances and practice of moving from the continuum of teacher centred teaching to student centred learning, she found a gap that "while in my mind (I know) I should have to be a facilitator in order to do the group work, I found myself being a teacher: a teacher who talks a lot!"

The qualitative data collected from the open ended question are also consistent with the above findings. In responding to the open ended question: "Please list three benefits for using ICT for classroom teaching and learning" in the pre-course and post-practicum survey, the frequency of the 118 general participants' perceptions on using ICT varied greatly in teacher centred use and student centred use (see Table 1). There was a significant increase in the frequency of using ICT for enhancing teacher instruction in the post-practicum survey, nearly 2.5 times more than that in the pre-course survey. After the practicum, there was a significant decrease in the frequency of using ICT for student centred use.

Table 1: Benefits from using ICT for classroom teaching and learning

\begin{tabular}{|c|c|c|c|}
\hline & Major benefits & $\begin{array}{c}\text { Pre-ICT course } \\
\text { survey }\end{array}$ & $\begin{array}{c}\text { Post-practicum } \\
\text { survey }\end{array}$ \\
\hline \multirow{5}{*}{$\begin{array}{l}\text { Teacher centred } \\
\text { use }\end{array}$} & Attracting/retaining student attention & 141 & 136 \\
\hline & Enhancing instruction & 44 & 103 \\
\hline & Professional development & 7 & 3 \\
\hline & Alternative assessment & 6 & 2 \\
\hline & Classroom management & 0 & 4 \\
\hline \multirow{4}{*}{$\begin{array}{l}\text { Student centred } \\
\text { use }\end{array}$} & Constructing their own understanding & 42 & 2 \\
\hline & Hands on learning & 37 & 7 \\
\hline & Exposure to technology & 33 & 4 \\
\hline & Collaborative learning & 8 & 6 \\
\hline
\end{tabular}

An interpretation of this decrease may suggest that the general participants were more idealistic about student centred use of ICT prior to the practicum. They acknowledged the importance of equipping students with IT skills and they had an intention to create a student centred learning environment to encourage active and constructive learning. The 10-week practicum, however, brought them closer to classroom reality. Most of them thus resorted to the one-directional instructional style, which resulted in the increase in teacher centred use. This raises an important question: What are the major challenges for the participants to ensure congruency between their espoused beliefs and practices? We answer this question in the following paragraphs.

\section{Decision making: Negotiating with multiple realities}

The focus participants identified multiple challenges that influenced their decision making on whether to use ICT and how to use it for classroom teaching and learning. These challenges are situated in the institutional contexts of the school and personal contexts that influence their decision for using or not using ICT. 
In the institutional contexts of the school, all the focus participants ranked a lack of technology facilities as the top challenge. For example, seven focus participants pointed out that although most classrooms in Singapore were equipped with an LCD projector and at least one computer station, they found that most of the facilities in their classroom were outdated and/or could not function properly, and were slow to set up. In addition, the physical layout of the classroom and computer laboratory was not user friendly for implementing student centred learning activities. A focus participant commented:

The classroom itself does not have any ICT related tools [for group activities]. In the computer lab, the physical environment was arranged in such a way [in rows] that was more effective for teacher centred teaching approaches, so I did not actually attempt ICT for any learning strategies...

Secondly, the focus participants were overwhelmed by managing competing agendas in their practicum schools. On one hand, they felt the pressure to integrate technology into teaching imposed by the school administrators: "How can you not use ICT when you are required to?" On the other hand, they lacked modeling from their cooperating teachers and other colleagues in schools where the use of ICT was not in the school culture. They observed few teachers used ICT in the classroom. This is reflected by one participant's comment: "Only preservice teachers use ICT for classroom teaching" (Second interview). When supervised and assessed by the cooperating teachers who did not perceive technology integration as a priority, the focus participants did not have much flexibility to step outside their cooperating teachers' teaching parameters and pre-set routines and had to "go with the flow" (Second Interview).

Thirdly, the majority of the focus participants saw no urgency to integrate ICT and student centred approaches, because "it [the school] is test driven, examination driven, not ICT driven" (First Interview). Another focus participant echoed: "You have to finish certain syllabus. They [schools] actually emphasise on covering the syllabus so the flexibility for using ICT is not emphasised" (First Interview). During the teaching practicum, this focus participant could not use ICT as frequently as she had anticipated:

It is unfortunate that for Primary Five students I have no opportunity to bring them to computer lab throughout my practicum. I really wanted to do that, but the limitation is [that] a lot of time we have to follow the syllabus (Second Interview).

In the personal contexts, some focus participants had limited understanding about technology integration, they had "a culture of fear" (First Interview). They were not comfortable with classroom and time management issues when they implemented technology enhanced lessons. They also showed a fear of their capability to deal with technological problems (Bullock, 2004; Doering, Hughes \& Huffman, 2003). Furthermore, they had personal doubts, concerns and reservations. For example, one participant, who self reported herself as having a low comfort level for using ICT, questioned the purpose of using ICT in the first interview: "Why should I use a picture [on the computer] when I can show my students the real object?" (Pre-lesson Reflection). Additionally, she worried that using PowerPoint would give her less flexibility as a result of over-dependence on the pre-determined content. She concluded her biggest hurdle to overcome was "to convince myself to accept ICT because of my limited technology skills and knowledge". 
These findings are consistent with the survey result. Responses to the open ended question in the pre-ICT course survey: "What challenges will you anticipate when you plan to integrate ICT for your future teaching?" and "What challenges did you experience when you attempted to integrate technology into your instruction during the practicum?" in the post-practicum suggest, the general participants indicated a shift in the encountered challenges (Table 2).

Table 2: Challenges for technology integration

\begin{tabular}{|l|l|c|c|}
\hline \multicolumn{1}{|c|}{ Major challenges } & $\begin{array}{c}\text { Pre-ICT course } \\
\text { survey }\end{array}$ & $\begin{array}{c}\text { Post-practicum } \\
\text { survey }\end{array}$ \\
\hline \multirow{3}{*}{$\begin{array}{l}\text { Institutional } \\
\text { contexts }\end{array}$} & Technology availability & 21 & 40 \\
\cline { 2 - 4 } & Technology functionality & 20 & 33 \\
\cline { 2 - 4 } & Student hands on learning experiences & 16 & 7 \\
\cline { 2 - 4 } & Students' ICT competency and attitudes & 14 & 4 \\
\cline { 2 - 4 } & Classroom management & 16 & 27 \\
\cline { 2 - 4 } & Available instruction time & 26 & 2 \\
\hline \multirow{2}{*}{$\begin{array}{l}\text { Personal } \\
\text { contexts }\end{array}$} & Personal technology proficiency & 11 & 10 \\
\cline { 2 - 4 } & Personal commitment (time and effort) & & 11 \\
\hline
\end{tabular}

There was a significant increase for the three external factors: technology availability, technology functionality and available instruction time. This increase indicated these external factors served as major barriers in preventing the general participants from adopting ICT extensively for classroom teaching and learning. There was a significant decrease in one of the internal factors: personal technology proficiency. It may suggest that the general participants self reported an increase in personal technology proficiency. Therefore, it became less challenging than they thought initially.

\section{Using ICT for promoting teacher centred instruction}

Overwhelmed by the abovementioned challenges during the teaching practicum, the majority of the focus participants showed a tendency to shift from student centred orientation to teacher centred orientation. They chose not to integrate technology for student centred learning to any significant degree in their classrooms. Two participants occasionally used PowerPoint to enhance their own teaching. The other five used PowerPoint presentations frequently for the reinforcement of conventional teaching approaches as they articulated in their first interview. For example, one participant stated: "I think I still have to go into the mainstream of using the PowerPoint."

Among the 13 lessons observed in the classroom for the seven focus participants, four participants used PowerPoint presentations primarily to enhance their teacher centred instruction. They embedded pictures, Flash animations, and streamed movies in their PowerPoint presentations as "tuning in" activities for their lessons. They found that PowerPoint was able to "sustain students' attention" and "replace textbook or teacher" (Second Interview). One of them specifically explained the rationale for using ICT as a presentation tool:

The use of PowerPoint or the ICT part has allowed me to cover more things ... Using PowerPoint I can actually teach faster and more importantly, I can put the manipulations - their abstract part and the working part - side by side. So they can see the two things happening at once ... this one reinforces their understanding. (Second Interview) 
Two observations of his lessons confirmed his reported use of PowerPoint in the classroom. Another focus participant summarised his use of ICT as follows:

Most of the time, [I] used Flash [animation] to tune in. Then during the lesson I used the PowerPoint to present the content. Then for ending or revision sometimes I used PowerPoint and sometimes we just did paper work (Second Interview).

It was interesting that one participant was pushed by her Primary 4 (Grade 4) students, who constantly made demands of her to use ICT in her teaching. In order to accommodate her students' expectations and overcome her limited personal ICT skills, she asked her peers for support. She got the copies of her peers' PowerPoint slides and spent more than three hours modifying one particular lesson. She said, "I have come across a lot of difficulties and I finally figured out how to do it ... I think it is because I really put in my efforts in learning it and I know I will use it in future" (Second Interview). Reflecting on her first attempt on using PowerPoint slides during her teaching practicum, she noticed the difference in her teaching practice:

In my previous teaching, as a teacher, my talk takes up $80-90 \%$ of the lesson time. For the lesson with ICT, the ratio of teacher talk and student talk is about 50\% to 50\%

(Second Interview)

The answers to the open ended question pertaining to the use of ICT seem to confirm the above qualitative finding. Responses to "Please tell us in detail what and how you would like to use ICT for your future teaching practicum" in the post-course survey, and "Please tell us in detail what and how you used ICT during your teaching practicum" in the post-practicum survey, suggest there was a significant decrease in students' use of ICT during the teaching practicum.

Table 3: Ways of using ICT

\begin{tabular}{|l|l|c|c|}
\hline \multicolumn{1}{|c|}{ Using ICT } & $\begin{array}{c}\text { Pre-ICT course } \\
\text { survey }\end{array}$ & $\begin{array}{c}\text { Post-practicum } \\
\text { survey }\end{array}$ \\
\hline Student use & Online searching for information & 29 & 3 \\
\cline { 2 - 4 } & PowerPoint & 11 & 2 \\
\cline { 2 - 4 } & Interactive games & 9 & 5 \\
\hline \multirow{3}{*}{ Teacher use } & PowerPoint presentations & 44 & 92 \\
\cline { 2 - 4 } & $\begin{array}{l}\text { Multimedia resources (audio, video clips from } \\
\text { YouTube, and Flash) }\end{array}$ & 20 & 48 \\
\cline { 2 - 4 } & CD (software) & 16 & 7 \\
\cline { 2 - 4 } & Searching additional Internet information & 12 & 14 \\
\hline
\end{tabular}

Evidently, a majority of the general participants chose to use ICT as a presentation tool to enhance their instruction. The ways of using ICT for classroom teaching also reflected the benefits the general participants perceived after the practicum. Most of the general participants did not seem to engage their students in using ICT for classroom teaching and learning.

\section{Using ICT to promote student centred learning}

Three focus participants - Harold, Max, Henry (pseudonyms) - stood out from the rest of the focus participants for their self initiative attitude, and a "try it out" spirit in the use of ICT in their classrooms. They broke down the barriers and created their own opportunities to integrate technology to enhance student learning during their teaching practicum. 
Harold, who rated himself as having a high level of technology skills, distinguished himself by constantly exploring hands on learning opportunities for his students. During the second interview, he reported that in addition to using the PowerPoint application on a regular basis, he created some hands on learning opportunities in the computer lab for self regulated learning for his students during his teaching practicum. For example, during the one observed lesson conducted in a computer laboratory, Harold allowed his high ability Primary 3 students to work individually on the website designed and promoted by the Ministry of Education and played games as an introduction to the lesson. He seemed very satisfied with the lesson and perceived that it was "student centred learning because the students were involved in hands on activities" (Second Interview).

Max self reported to have a medium level of technology competency in the pre-course survey. He stood out by trying different technology applications. For example, during our first lesson observation, Max implemented a WebQuest activity, which he and his classmate developed for the ICT course at NIE, in his teaching practicum. He asked his students to work on authentic scenarios and write a police report. He was convinced by his own practice: "ICT really can enhance teaching and learning in the classroom" (Second Interview). In another observed lesson, after showing the students an online report and a Flash animation on plagiarism, Max arranged his students in groups of three to discuss the issue from three different perspectives (the party whose copyright was violated, the person who violated it, and a third person). He ended the lesson by having his students present their findings. He seemed to have developed a professional judgment for using ICT, knowing when to and when not to use ICT. He shared:

[Using] ICT would mean getting students more student-centred. But it doesn't mean that when we don't use ICT, we are not student centred. I think ICT is the major tool that we can use to let them learn on their own (Second interview).

Like Max, Henry tried adopting ICT for student centred learning during the practicum. Henry self reported to having a high level of technology competency in the pre-course survey. In our first observed lesson, he designed five learning stations for a revision lesson for his Primary 2 students. In one station he set up two laptops for a group activity to use "Hot Potatoes" - an online self assessment tool to get instant feedback. Henry was excited to see that the students were "very engaged throughout the entire activity in class" (Post-observation Discussion). He began to appreciate such experiences for "benefit[ing] them a lot" by "boost[ing] their confidence" (Postobservation Discussion). Reflecting on his own practice, Henry seemed to have developed better professional judgment in knowing how to use ICT to maximise his students' learning. For example, in our second observation, he chose not to use ICT for a topic on team building. He justified his reasoning: "because the lesson was very activity based where students will really get a feeling of cooperation and team work" (Pre-lesson Reflection). In addition, as a result of the lack of ICT resources in the classroom, it would be "pretty hard to really work together with ICT which they [the Primary 2 student] are not familiar" (Second Interview). His own experiences reinforced his previous beliefs in the use of ICT and student centred learning.

It was encouraging that Harold, Max and Henry began thinking about making a positive impact on technology integration as preservice teachers. Harold thought of creating a school culture by becoming a technology advocate: "I am more interested to convince my peers, my colleagues to use ICT in classroom because I feel that if the 
more teachers will use ICT I think this environment thing (student centred learning) will come up, and gradually you will see more students, more teachers are more willing to use..."(Second Interview). Max elaborated his thinking for a systematic change: "I think Rule Number 1 is to be a role model. I think that you got to be able to use technology. I think the next step is to share how you actually conduct the lesson within the department" (Second Interview). Similarly, Henry found "it was very encouraging" (Post-lesson Reflection) when he received positive feedback from his cooperating teachers and other teachers in the school. He was approached by other teachers for the lesson plans and the resources he had created for the lesson. He began to perceive himself as a change agent during the second interview:

Well, to implement ICT, I think [it] really takes a lot of effort because some teachers are not really ICT savvy, they have great difficulties even [in] producing very basic PowerPoints .... so to be a great leader, I think it's really tough but I think it's a do-able job. You can try it but the success to it [ICT] being implemented really need to be seen.

Henry was looking forward to making a contribution that could be "more applicable to the school environment" (Second Interview).

\section{Discussions and implications}

There are some constraints to this one year mixed methods study. For example, this study was exploratory in nature. Our findings may also be biased because of the limited number of observations of classroom teaching for each focus participant during the ten-week practicum. However, the mixed methods design that we employed allowed us to explore a complex inquiry from different directions.

There are three major findings from this study. The first finding is the positive impact of the technology course. Evidently, the preservice teachers increased their technology skills and comfort level for adopting student centred teaching approaches, and developed a constructivist orientation towards teaching and learning after taking the ICT course. This is consistent with the findings of other studies conducted with preservice teachers in Singapore (Chan, Tan \& Khoo, 2007; Teo, Chai, Hung \& Lee, 2008). However, there is an incongruence between preservice teachers' teaching practices and their espoused beliefs (Lim \& Chan, 2007). For example, the majority of the participants could not draw a connection between the constructivist orientation and the effective use of information technology to enhance student centred learning. They could hardly translate their increased skills and comfort level into student centred learning, while caught in the midst of conflicting demands and multiple challenges during their teaching practicum. Consequently, they talked the "talk" and walked the "walk" - by using ICT routinely only to enhance teacher centred instruction.

On the other hand, it confirmed that there was limited use of technology for promoting higher order thinking and cooperative learning during the field placements (Bird \& Rosaen, 2005; Kay \& Knaack, 2005; Wright \& Wilson, 2005). However, this finding differed from previous studies conducted in other countries where it was reported that preservice teachers tended not to use ICT routinely in the field placements (Brown \& Warschauer, 2006; Kay \& Knaack, 2005; Moursund \& Bielefeldt, 1999). Particularly, this study identifies multiple challenges that preservice teachers learn to negotiate within the institutional and personal contexts. This finding implied that it is easy for preservice teachers to make certain positive changes in thinking about using ICT 
effectively for promoting student learning from the coursework. But it is difficult to sustain such changes. Although the problem of espoused beliefs not translating into classroom practice is a universal one, this paper provides insight into the practices of preservice teachers and the barriers which impede their use of technology.

The second major finding suggests that the new generation of "digital natives" - the primary school students - became the force that pushed preservice teachers to stretch beyond their comfort zone with regard to using ICT in their classrooms. As discussed in the previous section, one participant was pushed by her Primary 4 students to use ICT in her teaching and learning. However, as with most of the focus participants, this participant cannot sustain her increased motivation to adopt ICT when she encounters multiple constraints. Although she did not change dramatically in her thinking and action about using ICT in the classroom, she was pushed by her students to start using ICT in her teaching and learning. For most of the participants, they also identified the urgency to expose their students to technology for their future success.

The third major finding suggests that a small number of the preservice teachers started to develop a better understanding of technology based pedagogy from their own trial and error technology field practices. When they reinforced their constructivist orientations from their own practices, they began to develop a synergy of their constructivist perception in teaching, student centred teaching approaches, and technology integration from their own practices. They promoted such an understanding of technology based pedagogy by demonstrating their leadership potential in their assigned schools. They began to demonstrate their positive impact by modeling and sharing their experiences with their cooperating teachers.

The solution to the lack of innovative use of ICT by preservice teachers lies not in more courses and standalone workshops, but in a sustained program in which preservice teachers can learn how to integrate technology into teaching and learning from observing, interacting with, and receiving targeted feedback (Duffy \& Cunningham, 1996). Moreover, Max, Harold and Henry developed a better understanding of technology based pedagogy from their own teaching practice. Therefore, the practical implications are that teacher education programs need to adopt various strategies to nurture a sophisticated, constructivist view of technology integration. For example, teacher education programs need to challenge preservice teachers' idealistic constructivist beliefs by involving them in critical reflection upon their own practice (Gao, 2005), providing on going guidance, modelling (Fleming, Motamedi, \& May, 2007; Garcia \& Rose, 2007; Hughes, 2005; Lipscomb \& Doppen, 2005) and collaboration (Russell et al., 2003). Therefore, it is important to promote collaboration between preservice teachers and students, and between schools and teacher education institutes to create a synergy which allows both to bring their expertise together to construct a richer learning environment, both for preservice and inservice teachers. The schools can provide more opportunities for preservice teachers to develop leadership potential by allowing them to share their practice and help practising teachers use ICT to engage students in learning.

Based on the results of this study and the limitations discussed, future research can look into several areas to prepare preservice teachers to integrate ICT more effectively in student centred learning activities. Future studies can try to investigate the possibility of appointing university faculty in educational technology fields as ICT mentors to preservice teachers during their teaching practicum. Additional research studies can examine different ways of helping preservice teachers' development of 
technology based pedagogy. Future research can investigate collaborative efforts among teacher education institutions and schools, between preservice teachers and their students, and among preservice teachers. We also noticed that some preservice teachers had begun to emerge as change agents for technology integration when they were able to develop performances of understanding of using ICT to promote student centred learning. Longitudinal research studies could be one of the many ways to investigate beginning teachers' role in advocating technology integration during the initial years of their teaching careers.

\section{Conclusion}

Singapore schools are gearing towards student centred teaching and learning with a constructivist vision in education. Therefore, it is a top educational priority to prepare a new generation of teachers who can use ICT innovatively to promote student centred learning. The major findings of this study reveal one technology course is not sufficient for preservice teachers to sustain their increased technology competency, comfort level and motivation for using ICT to promote student centred learning. The development of technology based pedagogy is an active, on going process situated in multiple contexts. It is therefore imperative for teacher education programs to adopt various strategies to guide, model and support preservice teachers' development of technology based pedagogy, until it becomes an integral part of their professional growth. Derived from multiple methods, this study contributes to the knowledge base of initial teacher preparation, and informs teacher education programmes on how to better prepare preservice teachers to become technology-competent teachers, and change agents for technology integration.

\section{Acknowledgments}

The work represented in this paper is funded by a Learning Sciences Laboratory research grant, number LSL0306, at the National Institute of Education, Singapore. Special thanks to the ten preservice teachers who participated in the qualitative portion of the research for their contributions.

\section{References}

Andersson, S. B. (2006). Newly qualified teachers' learning related to their use of information and communication technology: A Swedish perspective. British Journal of Educational Technology, 37(5), 665-682.

Ball, D. L. \& McDiarmid, G. W. (1987). Understanding how teachers' knowledge changes. National Center for Teacher Education Colloquy, 1(1), 9-13.

Bird, T. \& Rosaen, C. L. (2005). Providing authentic contexts for learning information technology in teacher preparation. Journal of Technology and Teacher Education, 13(2), 211-221.

British Columbia Ministry of Education (1999). Conditions for success: Report of the teaching, learning and education technology advisory committee to the British Columbia Ministry of Education. Victoria, BC: Ministry of Education.

Brophy, J. (1991). Advances in research on teaching: Teachers' knowledge of subject matter as it relates to their teaching practice (Vol. 2). Greenwich, CT: JAI.

Brown, D. \& Warschauer, M. (2006). From the university to the elementary classroom: students' experiences in learning to integrate technology in instruction. Journal of Technology and Teacher Education, 14(3), 599-621. 
Bullock, D. (2004). Moving from theory to practice: An examination of the factors that preservice teachers encounter as the attempt to gain experience teaching with technology during field placement experiences. Journal of Technology and Teacher Education, 12(2), 211-237.

Cannella, G. S. \& Reiff, J. C. (1994). Individual constructivist teacher education: Teachers as empowered learners. Teacher Education Quarterly, 21(3), 27-38.

CEO Forum on Educational Technology (2000). School technology and readiness: A focus on digital learning. [viewed 1 Aug 2007] http:/ / www.ceoforum.org/downloads/report3.pdf

Choy, D., Wong, A. \& Gao, P. (2008). Singapore's preservice teachers' perspectives in integrating information and communication technology (ICT) during practicum. Proceedings of AARE Conference 2008. Brisbane, 30 Nov to 4 Dec. http:/ / www.aare.edu.au/08pap/ cho08326.pdf

Chan, K. W., Tan, J. \& Khoo, A. (2007). Pre-service teachers' conceptions about teaching and learning: A closer look at Singapore cultural context. Asia-Pacific Journal of Teacher Education, 35(2), 181-195.

Dawson, K. (2006). Teacher inquiry: A vehicle to merge prospective teachers' experience and reflection during curriculum-based, technology-enhanced field experiences. Journal of Research on Technology in Education, 38(3), 265-292.

Dexter, S. \& Riedel, E. (2003). Why improving preservice teacher educational technology preparation must go beyond the college's walls. Journal of Teacher Education, 54(4), 334-346.

Doering, A., Hughes, J. \& Huffman, D. (2003). Preservice teachers: Are we thinking with technology? Journal of Research on Technology in Education, 35(3), 342-362.

Duffy, T. M. \& Cunningham, D. J. (1996). Constructivism: Implications for the design and delivery of instruction. New York: Simon \& Schuster Macmillan.

Fleming, L., Motamedi, V. \& May, L. (2007). Predicting preservice teacher competence in computer technology: Modeling and application in training environments. Journal of Technology and Teacher Education, 15(2), 207-231.

Garcia, P. \& Rose, S. (2007). The influence of technocentric collaboration on preservice teachers' attitudes about technology's role in powerful learning and teaching. Journal of Technology and Teacher Education, 15(2), 247-266.

Gao, P. (2005). Learning to teach with information technology: Preservice teachers' perspectives and experiences across their three semester preparation. Dissertation Abstracts International, 66(10), p. 3550. (UMI No. 3194016).

Glaser, B. G. \& Strauss, A. L. (1967). The discovery of grounded theory: Strategies for qualitative research. Chicago: Aldine Publishing Company.

Hollingsworth, S. (1989). Prior beliefs and cognitive change in learning to teach. American Educational Research Journal, 26(2), 160-189.

Hughes, J. (2005). The role of teacher knowledge and learning experiences in forming technology-integrated pedagogy. Journal of Technology and Teacher Education, 13(2), 277-302.

International Society for Technology in Education (2000). NETS for teachers. [viewed 1 Jan 2008, verified 1 Nov 2009] http: / / www.iste.org/Content/NavigationMenu/NETS/ ForTeachers/2000Standards/NETS_for_Teachers_2000.htm

Johnson, G. \& Howell, A. (2005). Attitude toward instructional technology following required vs. optional WebCT usage. Journal of Technology and Teacher Education, 13(4), 643-654.

Jonassen, D. H., Peck, K. \& Wilson, B. G. (1999). Learning with technology: A constructivist approach. Upper Saddle River, NJ: Prentice-Hall.

Judge, S. \& O'Bannon, B. (2007). Integrating technology into field-based experiences: A model that fosters change. Computers in Human Behavior, 23(1), 286-302. 
Kay, R. H. (2006). Evaluating strategies used to incorporate technology into preservice education: A review of the literature. Journal of Research on Technology in Education, 38(4), 383-408.

Kay, R. H. \& Knaack, L. (2005). A case for ubiquitous, integrated computing in teacher education. Technology, Pedagogy and Education, 14(3), 391-412.

Lerman, S. (1989). Constructivism, mathematics and mathematics education. Educational Studies in Mathematics, 20(2), 211-223.

Lim, C. P. \& Chan, B. C. (2007). MicroLESSONS in teacher education: Examining pre-service. teachers' pedagogical beliefs. Computers \& Education, 48(4), 474-494.

Lincoln, G. E. C. \& Guba, E. G. (1985). Naturalistic inquiry. London: Sage.

Lipscomb, G. B. \& Doppen, F. H. (2005). Climbing the STAIRS: Pre-service social studies teachers' perceptions of technology integration. International Journal of Social Education, 19(2), 70-82.

McNabb, M., Hawkes, M. \& Rouk, U. (1999). Critical issues in evaluating the effectiveness of technology. Washington, DC: U.S. Department of Education. [viewed 1 May 2008] http:/ / www.ed.gov/rschstat/eval/tech/techconf99/ confsum.pdf

McIntyre, S. R. \& Tlusty, R. H. (1995). Computer-mediated discourse: Electronic dialogue journaling and reflective practice. Paper presented at the annual meeting of the American Educational Research Association, San Francisco, CA. http:/ / www.eric.ed.gov:80/ERIC WebPortal/ contentdelivery/ servlet/ERICServlet?accno=ED385232

Moursund, D. \& Bielefeldt, T. (1999). Will new teachers be prepared to teach in a digital age? A national survey on information technology in teacher education. Santa Monica, CA: Milken Exchange.

Mullen, L. (2001). Beyond infusion: Preservice students' understandings about educational technologies for teaching and learning. Journal of Technology and Teacher Education, 9(3), 447466.

National Council for Accreditation of Teacher Education, Task Force on Technology and Teacher Education (1998). Technology and the new professional teachers: Preparing for the 21st century classroom. Washington DC: National Council for Accreditation of Teacher Education.

Onwuegbuzie, A. J. \& Teddlie, C. (2003). A framework for analyzing data in mixed methods research. In A. Tashakkori \& C. Teddlie (Eds.), Handbook of mixed methods in social and behavioral research (pp. 351-384). Thousand Oak, CA: Sage.

Patton, M. Q. (1990). Qualitative evaluation and research methods (2nd ed.). Thousand Oaks, CA: Sage.

Reeves, T. C. (1998). The impact of media and technology in schools: A research report prepared for the Bertelsmann Foundation. [viewed 1 May 2008, verified 1 Nov 2009] http: / / it.coe.uga.edu/ treeves/ edit6900 / BertelsmannReeves98.pdf

Russell, M., Bebell, D., O'Dwyer, L. \& O'Connor, K. (2003). Examining teacher technology use: Implications for preservice and inservice teacher preparation. Journal of Teacher Education, 54(4), 297-310.

Singapore Ministry of Education (2002). Masterplan for IT - Masterplan review. [viewed 1 May 2008, not found 1 Nov 2009]

http: / / www.moe.gov.sg/edumall/mpite/ overview/index.html

Strauss, A. L. (1987). Qualitative analysis for social scientists. Cambridge University Press. 
Strudler, N., McKinney, M.O., Jones, W.P. \& Quinn, L.F. (1999). First year teachers' use of technology: Preparation, expectations, and realities. Journal of Technology and Teacher Education, 7(2), 115-130.

Stulmann, J. (1998). A model for infusing technology into teacher training programs. Journal of Technology and Teacher Education, 6(2/3), 125-140.

Swain, C. (2006). Preservice teachers self-assessment using technology: Determining what is worthwhile and looking for changes in daily teaching and learning practices. Journal of Technology and Teacher Education, 14(1), 29-59.

Teo, T., Chai, C. S., Hung, D. \& Lee, C. B. (2008). Beliefs about teaching and uses of technology among pre- service teachers. Asia Pacific Journal of Teacher Education, 36(2), 165-176.

Vannatta, R. A. \& Beyerbach, B. (2000). Facilitating a constructivist vision of technology integration among education faculty and preservice teachers. Journal of Research on Computing in Education, 33(2), 132-148.

Willis, J. \& Mehlinger, H. (1996). Information technology and teacher Education. In J. Sikula, T.J. Buttery \& E. Guyton (Eds.), Handbooks of research on teacher education (2nd ed., pp. 978-1029). New York: Simon and Schuster Macmillan.

Willis, J., Thompson, A. \& Sadera, W. (1999). Research on technology and teacher education: Current status and future directions. Educational Technology Research and Development, 47(4), 29-45.

Wright, V. H. \& Wilson, E. K. (2005). From preservice to inservice teaching: A study of technology integration. Journal of Computing in Teacher Education, 22(2), 49-55.

Dr Ping Gao (corresponding author), Assistant Professor, is with the Learning Sciences and Technologies Academic Group at the National Institute of Education, Nanyang Technological University, Singapore. Her research interests include teacher learning, technology integration, program evaluation, and qualitative research. Email: ping.gao@nie.edu.sg

Dr Doris Choy, Assistant Professor, is with the Learning Sciences and Technologies Academic Group at the National Institute of Education, Nanyang Technological University, Singapore. Her areas of research include: teacher education, integration of information and communication technology in schools, teacher education and designing and managing instructional design projects.

Dr Angela F.L. Wong, Associate Professor, is with the Learning Sciences and Technologies Academic Group, National Institute of Education, Nanyang Technological University, Singapore. She lectures in instructional technology and educational psychology courses. Her research interests include learning environments, instructional technology and teacher education.

Miss Jing Wu, Research Associate, is with the Learning Sciences and Technologies Laboratory, National Institute of Education, Nanyang Technological University, Singapore. 